\title{
The Role of the Educational Developer in the Improvement of University Teaching
}

\section{SUSAN WILCOX}

Queen's University

\begin{abstract}
As educational development (ED) programs become entrenched in many universities and a growing number of academics are engaged in educational development work, it is important that the nature of the ED occupation/profession is defined. The study reported in this paper examined the characteristics of persons holding educational development appointments in Ontario universities. The intent was to develop an accurate picture of the respondents as a professional group. The study provides insight into how educational developers make sense of their work.
\end{abstract}

\section{Résumé}

Au moment où de plus en plus de programmes de perfectionnement pédagogique sont intégrés dans de nombreuses universités et où un nombre croissant de professeurs sont engagés pour assurer ce perfectionnement, il s'avère important de définir le perfectionnement pédagogique comme profession. L'étude dont il est question dans cet article porte sur les caractéristiques des personnes qui occupent un poste dans ce domaine dans les universités ontariennes. Il s'agit là de donner une image précise de ces personnes comme corps professionnel. Cette étude donne un aperçu de la façon dont les formateurs en pédagogie universitaire conçoivent leur travail. 


\section{Introduction}

In Canadian universities, instructional development and faculty development are the most commonly used terms for efforts to improve university teaching and learning, while in other jurisdictions and contexts this field of work and study has been referred to variously as staff development, organizational development, academic development or professional development. Given that the overall intention of these interventions is to improve the quality of education through the development of educational knowledge and educational practices, the term educational development $(E D)$ serves usefully as a generic and inclusive descriptor for the field as a whole, and has thus found currency on the international scene (see for example, Baume \& Baume,1994; Gosling, 1996; Johnston \& Adams, 1996). In this article, I explore the role of the educational developer in teaching improvement initiatives, and examine the characteristics of persons who play that role in the university setting.

It is not uncommon (or unreasonable) to portray educational development as an institutional role and responsibility. However, it may be more realistic to describe ED as the day-to-day occupation of certain committed individuals with a mission to enhance and support teaching and learning in the university. Who are these individuals who assume responsibility for universities' efforts to improve instruction? What do they think of their own role in educational development? Although there is a large body of literature on the improvement of university teaching (written, for the most part, by educational developers), little of that literature describes the actual characteristics of developers or of the educational development occupation.

The research reported in this article is based on a survey of individuals who do educational development work in the Canadian university setting. My purpose in conducting this study was to learn more about ED from the perspective of the people who do the work, and to collect information and opinions that would allow me to characterize these developers as an occupational group. On a personal level, I work as an educational developer and I wanted to gain some insight about the ways my colleagues define their educational development practice and their role as practitioners. Finally, I had an interest in the question of whether ED work could or should be defined as a profession, and believed a study of developers could contribute to a better understanding of this issue. 


\section{Literature Review}

\section{Educational Development Activities/Programs}

One way to define the nature of ED work is to delineate the activities of institutionally supported units/programs. Smith (1991) offered this description of the "typical" Canadian teaching and learning centre:

These offices frequently publish newsletters, hold seminars, invite speakers and disseminate information on innovative teaching. As a rule the centres are small, with a permanent staff of one, and have very limited financial resources ... (p. 58).

Is the convention described by Smith an accurate one, or peculiar to the Canadian setting? Centra (1976), in a study of 1,000 U.S. institutions, found that the activities of faculty development centres typically consisted of direct assistance with instruction, workshops and seminars, grants and travel funds, assessment of teaching, development of traditional teaching practices, and publicity activities. A replication of this study done in 1984 showed little change - the same programs and services were still offered, although they were offered in more institutions than in 1976 (Erickson, 1986). Teather (1979) provided an international review of staff development activities; this edited book includes chapters written by academics directly involved in the field, describing concepts and practices in 12 different countries at a time when educational development was still a relatively young field. While Teather commented on the value of the comparative approach, in that "each contribution serves to throw into sharp relief particular and often different aspects of staff development" (p. 15), the activities described were remarkably similar in countries around the world. A study by Donald (1986) indicated that programs in Canadian universities provide similar services to those in the U.S. and other countries: workshops on teaching topics, newsletters or bulletins, courses for graduate teaching assistants, consultation with experts on teaching, incentives such as teaching awards or grants for the development of new courses or teaching methods, teaching evaluation services, teaching documentation centres, and a library of teaching resources.

Programs containing these elements have been evaluated and reported upon over the years, and there is considerable information available in the literature about the characteristics of effective interventions (see for example, Eble \& McKeachie, 1985) and the reasons for the 
limited influence of others (see for example, Elrick, 1990). There is, however, virtually no descriptive information about the persons who have designed and implemented these programs.

\section{The Role of Educational Developer}

Many of the concerns relevant to a discussion focused on the nature of the ED occupation are also addressed in the fertile literature on professionalization. Schein (1972), for example, has identified six criteria which may be used as a scale to judge any given occupational group in terms of its degree of professionalization; these criteria flag significant issues in characterizing the role of the educational developer:

1. The occupation is full-time, providing the principal source of income for practitioners.

2. Practitioners are assumed to have a strong motivation or calling as the basis for their choice of career and are assumed to have a stable life-time commitment to the career.

3. Practitioners form professional associations which define criteria of admission, educational standards, licensing or other formal entry examinations, career lines within the profession, and areas of jurisdiction for the profession.

4. Practitioners possess a specialized body of knowledge and skills, acquired during a prolonged period of education and training.

5. Practitioners are assumed to have a service orientation, meaning that expertise is used on behalf of the particular needs of the client.

6. Practitioners demand autonomy of judgment of their own performance. They are assumed to know better what is good for clients than the clients themselves; even if the client is not satisfied, practitioners permit only colleagues to judge their performance.

Whether or not it is appropriate to consider educational development as a professional practice, Schein's criteria provide a useful backdrop to a review of the literature concerning the role of ED practitioners, and can help us to make sense of arguments regarding the professional nature of ED work. 
When educational development first emerged in higher education in the mid- to late 60s, many of the same faculty members whose commitment to teaching had prompted them to promote ED within their institutions then took on the task of designing and implementing the first programs for their colleagues. In some cases, particularly in the research-intensive universities, instructional designers and/or educational researchers were employed in the first instructional development units. In other cases, the only prerequisite for appointment to an educational development position was experience as a university professor.

Lindquist (1978) described teaching improvement coordinators as "persons without formal training programs and professional associations to teach them their jobs. They learn on the job ..." (p. 257). Yet, he proposed the following criteria for selecting teaching improvement staff criteria which imply a certain kind of professional expertise: (a) knowledge of teaching/learning theory and practice related to diverse student needs; (b) knowledge of teaching improvement and professional/organization development theory and practice; (c) skill in interpersonal relations, group dynamics and communication; (d) ability to serve in expert, facilitating, brokering, leading and counselling roles toward college professors and administrators; (e) respect and empathy for diverse staff and students as well as interest in aiding their growth; (f) administrative, research and teaching technology skills; ( $g$ ) openness to various disciplines and various approaches to teaching and learning; (h) understanding of collegiate organization and the process of academic change; and (i) a sense of humour, unquenchable optimism and tolerance for uncertainty. If these were indeed the qualities required in a practitioner, it suggested that persons preparing for educational development practice would need to make a considerable and intentional effort to prepare themselves in these areas. Educational development was beginning to establish a professional identity of its own.

In the years since that time, educational development units have become a familiar presence in universities, and the field of practice has become associated with an extensive body of literature, contributing to a growing sense that there is an expert body of knowledge unique to the field of educational development. Weimer (1990) has nonetheless described contemporary developers as a "truly eclectic" group, and suggests that the varied backgrounds of American practitioners may have no bearing on the requirements of their current positions. While she 
acknowledges that "professionals" with an educational background in instructional development are available, Weimer states that "being 'educated' and 'trained' as an instructional developer is an asset, but . . . is not an essential requirement" (p. 161). There is some evidence, however, that Weimer's perception is not entirely accurate; the situation may be changing, or her view may not be shared by others who think of themselves as professional developers. For example, Porter, Lewis, Kristensen, Stanley, and Weiss (1993) report on a small, informal study of persons who had recently accepted faculty development positions at different types of American institutions. In response to the question, "What in your background and training made you feel 'right' for this faculty development position?", three common themes emerged: a) teaching experience in higher education, b) course work and/or training in teaching and learning in higher education, and c) work experience in faculty or TA development centres.

Another perspective on the nature of ED expertise is provided by Sell and Chism's (1991) list of the general competencies required for successful faculty developers in contemporary American universities. Necessary competencies include: (a) engaging in needs assessment; (b) designing and developing strategies that promote individual, pedagogical, curricular, and organizational growth; (c) organizing and implementing specific programs, projects and studies; (d) planning and delivering oral presentations; (e) producing print and non-print communications; ( $f$ ) conducting research about teaching and learning; and (g) establishing and maintaining consulting relationships.

Noting that we lack a definitive study of what directors of educational development units/programs do and how they prepare for their responsibilities, Wunsch (1993) proposed a list of competencies for directors, based on her knowledge of educational development and of administration in universities. Directors must adapt, enlarge, and apply the basic competencies posited by Sell and Chism (1991), and must be competent in seven additional areas: (a) seeing their part in the big picture; (b) understanding institutional policies and their impact on development programs; (c) getting and spending money; (d) selecting and motivating staff; (e) evaluating program quality and effectiveness; (f) developing and maintaining visibility and credibility; and (g) using networking and collaboration (Wunsch, 1993). 
The above lists of competencies tell us more about currently accepted models of American instructional/faculty development programs (including a significant measure of administrative responsibilities, and a presumed hierarchical relationship between members of educational development staff) than they do about the role of the developer although, admittedly, the two are difficult to separate. The role of developer appears to be that of fulfilling the terms of their institutional job description, which might be expected as educational development becomes entrenched in universities. Yet this characterization seems to indicate a lesser degree of professionalization, if Schein's provision that professionals demand autonomy of judgment of their own performance is taken seriously. Oddly enough, neither Sell and Chism (1991) nor Wunsch (1993) include any criteria for judging the level of ED competency, even though they use a particularly technical approach to describing competency in the field of educational development; this fact also reflects an occupation as yet ill-prepared to judge its own performance.

There is, however, recent evidence that some major steps are being taken towards professionalization, particularly in terms of defining criteria of admission and educational standards for practice. In 1994 the Staff and Educational Development Association (SEDA), in Great Britain, launched a professional accreditation program for staff and educational developers working in higher education. To be accredited, developers must prepare a portfolio that demonstrates that they can: (a) analyse the development needs of individuals and groups; (b) design a range of development programs; (c) use a wide and appropriate range of development methods; (d) act professionally in a consultant, mentor, or advisor role; (e) give feedback to staff on selected aspects of their work; (f) evaluate their own staff and educational development work; ( $\mathrm{g}$ ) perform the necessary support and administrative tasks; (h) employ personal and professional coping strategies; (i) reflect on their own personal and professional practice and development; ( $\mathrm{j}$ ) act as an advocate for staff or educational development; (k) support or initiate advances in staff or educational development theory or practice. For SEDA accreditation, developers must also demonstrate four areas of particular expertise which they use in their work (e.g., assessment, course design, teaching methods) and must show how their work embodies the values of staff and educational development, which are defined as: (a) understanding how people learn, (b) recognizing individual differences, (c) focusing on development, (d) promoting scholarship and 
professionalism, (e) emphasizing collaboration, (f) promoting equal opportunities, and $(\mathrm{g})$ reflecting on practice. Although published descriptions of values conducive to effective educational development practice are rare, McGrory (1994) does report on a discussion of values among faculty developers attending a conference in the U.S., noting that participants constructed the following "top five" list of values appropriate in a faculty development person: learning, collaboration, support, continuous improvement and open-mindedness. And Bergquist (1994) comments that, in the developmental culture of teaching improvement, collaboration is a key value, elaborated through developers' interests in dialogue, looking for commonalities, and relationship-building. Certainly many educators base their practice on the assumption that teaching is a moral activity in which values play a key role. Although Schein's list of criteria for determining an occupation's degree of professionalization does not include any item specifically related to values, most established professions do have codes of ethics which typically include reference to values - sometimes in a preamble, sometimes in the body of the code.

Will these standards for educational development practice and designated areas of expertise serve a legitimate and useful purpose in defining ED practice and preparing future ED practitioners? Further exploration of educational developer's characteristics, activities, and perspectives may shed some light on this question.

\section{Method}

This study of educational developers was driven by the following questions: Who are developers? How have they prepared for ED work? What are their responsibilities? It is an exploratory study to learn more about the people who play key roles in universities' educational development initiatives, and is meant to provide a focus for further research in this area. However, the results will be of some immediate practical use to educational development practitioners. A description and discussion of where educational developers are "coming from" may enhance the collaborative spirit that is characteristic of practitioners in this field.

\section{Data Collection}

For a variety of reasons, the sample consisted of educational developers in Ontario universities. First, choosing a population within a particular geographical and political area meant that all participants would be 
working in institutions shaped by similar cultural variables. Second, there are more educational developers in Ontario than in any other place in Canada, and the roots of educational development go back at least 15 years in the province. Most Ontario practitioners have the advantage of sufficient experience and historical perspective to make their opinions interesting. Finally, my own practice is in Ontario, and I was particularly interested in understanding more about the educational developers who work in situations similar to my own. I appreciated that results would not be generalizable to other jurisdictions, yet still believed such a study could contribute to a better overall understanding of educational development work.

Fourteen of 16 Ontario universities had educational development programs in operation at the time of the study, April 1992. Ten of the 14 universities had ED units; in the other four universities educational development was either the responsibility of a committee or an adviser. I surveyed by mail the 25 persons associated with educational development programs in these universities.

I constructed a twelve-item questionnaire (see Appendix A). Most questions were open-ended; they elicited information concerning unit staffing patterns, job responsibilities, research activities, academic background, job training, and career development patterns, and respondents' opinions concerning the nature of their professional involvement in educational development work, their most useful qualifications for this work, and characteristics of effective university teaching and effective educational development.

\section{Data Analysis}

I received and analyzed a total of 15 responses (60\% response rate). Responses represented all of the 10 universities with an ED unit. Data analysis focused on the development of an accurate description of the respondents as an occupational group. Frequencies were calculated for those items on the questionnaire that were best analyzed quantitatively. Open-ended items were subjected to qualitative content analysis, using an approach similar to that described by Lincoln and Guba (1985). No a priori categorization was used: units of data in the responses were coded and categories were constructed representing the themes and concepts that emerged from participants' actual responses, and the units of data were then sorted into the appropriate categories. For each of the questionnaire 
items analyzed in this way, the major themes or concepts in the responses were identified and reported. Finally, relationships among responses to the various questions were examined when appropriate.

\section{Findings}

\section{Respondents}

Fourteen of the 15 respondents were associated with the 10 educational development units, and provided information about staffing levels in these units. (Note that staff refers to professional/academic appointments and does not include secretarial or clerical staff, or student assistants.) The average number of staff in ED units (full- and/or part-time) was reported as 2.4 persons; many of the appointments in those units with more than one professional staff member were part-time appointments. (This suggests that the convention described by Smith was accurate.) Sixty percent of respondents were "in charge" of educational development at the institutional or faculty level; the remaining $40 \%$ were associates or staff in the educational development unit. Those in charge at the institutional level typically reported to the chief academic officer, i.e., vice-president/ provost, associate vice-president/provost, or president/principal.

\section{Role Responsibilities and Activities}

Responsibilities. Respondents reported a wide range of job responsibilities. To a large extent, their responsibilities reflect the usual range of typical educational development activities documented in the work of Centra (1976), Erickson (1986) and Donald (1986). Yet it is clear that the work of these developers is more comprehensive (and likely more elusive) than is suggested by listings of discrete categories of activities. Indeed, it seemed that many respondents considered any action that might bring about the goal of better teaching and learning to be part of their responsibilities.

Persons in charge of educational development in their universities included the following in their list of responsibilities:

- Advocacy for teaching.

- The design and delivery of programs; i.e., organizing activities.

- Communication and networking, both on campus and off.

- Acting as an expert resource on teaching and learning. 
- Staff supervision and administrative activities within the ED unit.

- Scholarly activity - writing and research on ED or on teaching and learning.

Persons not in charge of educational development listed the following types of responsibilities:

- Ongoing responsibility for specific programs or activities such as TA orientation, teaching a mini-course for graduate students, workshop presentations, etc.

- Consultations with faculty concerning teaching and/or curriculum issues.

- Materials preparation; newsletter and publications contributions.

- Special projects - the first-year-student experience, for example.

The role responsibilities of these Canadian practitioners were generally consistent with the educational development competencies listed by Sell and Chism (1991) and Wunsch (1993).

Research activities. Eighty-seven percent of respondents described research activities in the area of teaching and learning or educational development, including such activities as discipline-specific educational research, "non-traditional" research (such as action research or research aimed at policy development), scholarly conference presentations, or assisting colleagues with their research projects. Only two respondents $(13 \%)$ indicated that they had never conducted educational research.

\section{Role Development}

The following results relate to respondents' career development path, including pre-service and in-service education and training for ED work.

Academic background. Thirteen of the 15 respondents had completed a doctoral degree; two were doctoral candidates. The disciplinary "home" for six respondents $(40 \%)$ was psychology or applied psychology and for four respondents (27\%) was education (adult education, educational psychology, higher education, and instructional design).

Specialized job training. Ten respondents $(67 \%)$ said they had participated in at least one type of planned experience as training for their ED work: most specified workshops, short courses, and conferences; 
several listed credit courses, certificates, or academic degrees (in the areas of higher education, adult education, and educational psychology) as a form of job training. Five respondents (33\%) mentioned other less specialized experiences which were useful preparation for their ED work: teaching a graduate course on teaching, receiving feedback on their own teaching, cross-cultural experiences, working with small groups, research in educational psychology applied to higher education. Two respondents (13\%) specified self-directed on-the-job training and job experiences as a form of specialized job training.

Opinions about the "best" preparation for ID work. When asked their opinions about the best preparation for educational development work, most respondents suggested several factors in their background, listed here in decreasing order of frequency:

Experience: Not surprisingly, virtually every respondent indicated that experience was one of the best forms of preparation for their development work. Ten respondents $(67 \%)$ stated that their experiences as faculty members of their university (teaching experiences most notably, but not exclusively) were the best form of preparation for ED work. Other experiences cited by respondents as invaluable preparation included their experiences as students, personal growth experiences and, in one case, experience as a nursery school teacher!

Education and training: Interestingly, six respondents (40\%) suggested that their education had been useful in preparing them for ED - but each had a different background: philosophy, psychology, social work, measurement, higher education, and instructional design. Two respondents (13\%) indicated that training in counselling methods had been helpful to them.

Interests and attitudes: Four respondents (27\%) suggested that their personal interests and attitudes made them particularly well-suited to ED work. These respondents described themselves as "practical", "interested in alternatives", "committed to a future perspective", "non-threatening", "non-doctrinaire", and "willing to experiment".

Networking: Four respondents (27\%) mentioned their ability and/or actions to maintain connections with faculty, ED practitioners, and other related professions as crucial to their 
success as an educational developer. Active membership in professional organizations was a typically mentioned approach of these respondents.

Research: Two respondents $(13 \%)$ indicated that their research activities or interests prepared them for educational development work.

Overall, this list of factors felt by respondents to have best prepared them for practice was a broader range of factors than was noted in a recent study of educational development "new hires" in the U.S. (Porter et al., 1993).

Career path. Respondents were asked to describe how they came to be involved in educational development work. Notably, virtually all of the respondents reported that ED was not a planned career goal. The earliest stage at which any of the respondents became aware of educational development practice as a career option was as a graduate student. Most came to the work after many years in a discipline-based academic career. Respondents typically mentioned a critical opportunity - a specific experience that steered them in the direction of faculty/instructional development although that had not been their original goal. However, many also indicated a sincere and long-standing interest in teaching and learning, and suggested that this interest, in combination with an opportunity, led to their current situation.

Responses to this question about career paths were classified according to the factor that seemed to have the most significant influence on their career path:

Appointment: Three respondents $(20 \%)$ indicated that their involvement in ED work began when they were appointed to their positions (all three were in charge of development programs at their universities) by university administration on the basis of their past history, experiences, interests, and capabilities. These persons had full-time academic appointments at their university prior to their ED appointment.

Interest: Three respondents (20\%) suggested that the starting point for their ED work was their interest in teaching and in human development. This interest (which was not specifically in instructional/faculty development) led to opportunities in ED. 
Doctoral study: Three respondents (20\%) described situations in which their Ph.D. (in education) led almost immediately to university positions in educational development, although the doctorate had not been taken in preparation for such work. Use of ED services: Two respondents (13\%) indicated that becoming involved in their institution's educational development programs as regular faculty members led eventually to their ED practice.

Professional service activities: Two respondents (13\%) indicated that research or committee work undertaken early in their careers as a form of service to fellow faculty members led to greater involvement in issues related to the evaluation and improvement of teaching, and ultimately to involvement in ED work.

Other (13\%): One respondent simply stated that a combination of interests, academic background, and experiences led to his/her current position. One respondent stated "I needed a job"; interest in the work developed later through involvement in ED activities.

This description of the respondents' career development paths seems to support Weimer's (1990) observation that the varied background of educational developers may have no bearing on their current positions. Many of the respondents followed a career development path that has apparently been characteristic of ED work since its origins in the early 1970s - they established themselves in an academic department or discipline and then moved into educational development work as a service to their peers in academia. Others, however, worked as developers right from the beginning of their academic careers. Those who always worked as developers either were trained as experts in an area particularly valued in ED (instructional design or educational evaluation, for example) or had had on-the-job educational development training (typically, when they were graduate students) through association with more experienced practitioners.

\section{Role Identity}

Eight of the 15 respondents (53\%) described their educational development work as a professional career in itself (the term professional was 
not defined; see survey, Appendix A). The remainder described their development work as an ongoing collegial role played in addition to their primary role as an academic, or as a temporary stage in their academic career. These differences in respondents' role identities were largely unrelated to most other characteristics of the respondents. Most notably, views on teaching and instructional development were similar among all three categories of professional identity. However, a number of distinctions were noted between those who described their educational development work as their professional career, and those who described this work as a collegial or temporary role. The following results delineate these differences.

Job responsibilities. Those who described their educational development work as a professional career in itself typically used specific and detailed terms in describing programs and activities, and typically described themselves as expert resources. They also tended to describe quite a comprehensive package of responsibilities - a broad range of activities intended to address numerous issues and concerns. By contrast, those who described educational development as a secondary or temporary role tended to describe their responsibilities in either very global terms ("to promote excellence in teaching"), or in very narrow terms ("writing a newsletter"), and did not describe themselves as experts on teaching and learning.

Research activities. Six of the eight respondents (75\%) who described their educational development work as a professional career in itself indicated extensive ongoing involvement in research activities; the other two (both doctoral candidates) had also conducted research on teaching and learning, but to a lesser degree. Respondents who described their work as a secondary or temporary role had done little or no research on teaching and learning.

Academic background. Eighty-eight percent of those who consider their ED work as a professional career have an education or psychology background, in comparison with $29 \%$ of those who consider ED as a secondary or temporary role. All four of the respondents from the academic discipline of education indicated that ED is their primary professional career.

Career path. Those who described ED as their professional career seemed more likely than others to be concerned with issues of qualifications for their work. Many described a qualification step (either academic 
background or a specific work experience) in their career, or noted a seeming lack of appropriate qualifications for their positions in ED. Those who described ED as a temporary or secondary professional role simply described the turn of events by which they came to be doing ED work, with apparently little concern for their qualifications. In connection with this, it can be noted that all those respondents who described ED as a temporary stage in their academic career, and none of those who described ED as their professional career, stated that an appointment by university administration was the key factor in attaining their current positions.

\section{Practitioners' Educational Views}

The following results relate to respondents' educational perspectives, specifically the ways they define good teaching and effective educational development practices.

On teaching. There was a notably high degree of agreement among the 13 respondents who offered their opinions on effective teaching in higher education. In the view of many, effective teaching...

- is focused on student learning (9). Effective teaching supports student learning and student growth, and promotes selfdirected, active learning among students.

- is characterized by the mastery of teaching skills (6). Effective teachers are competent in the following areas: selecting and using appropriate teaching methods; having and drawing upon a wide variety of skills; responding and adapting with flexibility to students and the circumstances.

In addition, several respondents wrote that effective teaching ...

- is a scholarly activity (2). Teaching is enhanced when faculty's scholarly role is allowed to have an impact on their teaching; this includes developing a scholarship of teaching, and building links between the research and teaching aspects of faculty responsibilities.

- is characterized by personal growth of the teacher (1). The effective teacher is engaged in an ongoing process of personal development.

- establishes dialogue in the classroom (1). Effective teaching is an interactive conversation between teachers and learners. 
On educational development. Several factors were mentioned over and over again when respondents were asked to describe effective ED practice. In their view, educational development is effective to the extent that it...

- supports/assists faculty (8). Effective educational development provides what faculty need and want. It supports faculty's efforts at improvement, assists them by responding to their needs, helps them accomplish their own goals, and facilitates the work of the academic community.

- challenges the status quo (6). Effective educational development fosters critical self-reflection among faculty and within the university system. It questions current attitudes, practices and systems, and challenges and stimulates faculty to develop alternatives.

- empowers faculty (6). Effective educational development is led by faculty and includes opportunities for faculty to talk to one another about teaching and to learn from each other. Practitioners must therefore transfer responsibility for development activities to faculty; programs should be seen primarily as a catalyst for the ED efforts of faculty.

In addition, some respondents suggested that effective educational development practice...

- is adaptable and flexible (3). Effective educational development evolves over time, responding to the unique needs of each institution, adapting to changing circumstances, and developing with the faculty at each university.

- has administrative support (2). Effective educational development has the real support of university administration and works to establish political and organizational support for teaching.

- is accessible (2). Effective educational development is accessible to faculty in terms of location and climate. It works to establish trust among faculty, making it easier for faculty to participate in programs and activities.

- promotes better student learning (1). 
- collaborates with other university services to promotel develop effective teaching (1).

- emphasizes practical assistance rather than research(1).

- is a long-term commitment to faculty (1).

On the role of the practitioner. Twelve of the 15 respondents described a critical experience in the past six months that had either challenged or confirmed their ideas about educational development. These experiences included: having responsibility for difficult or new ED programs or establishing a new ED unit, coming face-to-face with financial cutbacks, considering the implications of developments in their field of study for their ED practice, using ED services to improve their own teaching, and having to respond to new scholarly developments in the field of higher education.

Analysis of their described experiences suggests that there are some basic, although not necessarily shared, principles underlying their approach to ED work: The effective developer...

- recognizes that how educational development work is done has as much impact as what is done.

- seeks intellectual challenges and thinks through what the goals of programs are.

- responds to the specific, expressed needs of faculty.

- not only designs programs, but also delivers them, to keep in touch with the front lines of improvement efforts.

- accepts the political nature of the job and works to establish administrative support.

- provides support for teachers who are trying to make changes, but accepts that faculty are responsible for their own development and may choose not to change.

- remembers that ongoing one-on-one work with faculty can be a very rewarding approach to teaching improvement.

- experiences being on the "receiving" end of ED services, if possible.

- focuses faculty attention on student development and the impact of teaching on students. 
The articulation of such principles as these, arising from analysis of educational developers' experiences, follows in a tradition that is quite important in the educational development literature (see for example, Gaff, 1975; Lindquist, 1978; Schuster \& Wheeler, 1990; Weimer, 1990; West, 1989). By reflecting on their own critical experiences, or those of their colleagues, developers are able to develop guidelines or "tips" for practice, helpful in understanding and improving one's own practice, and presumably useful for beginning developers.

\section{Discussion}

While it is important to appreciate the unique characteristics of the individuals who participated in this study, it is nonetheless possible to present a profile of a typical educational developer in an Ontario university (see Table 1), which may be useful in understanding educational developers as a group.

Generally, the respondents made it clear that they need to feel that educational development is useful, necessary, responsive - and that it works. These educational developers are interested in change, like to be helpful, and want to feel that they are instrumental in bringing about change. They are especially interested in changes that will bring about better faculty consideration of student needs. They want to be intellectually challenged, to use their skills to do a good job, to feel connected with faculty, and to feel that they are providing a useful service to faculty. Positive response to their efforts is gratifying - they are both comforted and challenged when their enthusiasm about teaching is shared by others. They want to keep faculty, and not educational developers, at the center of the development process, and can be frustrated when faculty do not seem interested in taking responsibility for educational development. Finally, it is clear that they do not like to feel marginalized, isolated, or as though their services are taken for granted. Educational developers, clearly committed to their work, would like to feel that the work they do is valued and supported by the university community.

The developers in this study assume responsibility for a very broad range of initiatives - advocacy, programming, expert consultancy, etc. In fact, many feel they should be prepared to do anything that may improve the environment for teaching and the quality of teaching in the university. Yet they have insignificant real power, in terms of direct authority or staff resources, to implement change. They are high on the 
Table 1

\section{A Profile of the Typical Educational Developer}

- connected to the university's educational development unit

- works with 1-2 other educational developers

- reports to the university's chief academic officer (in charge) OR reports to the director of the ED unit (not in charge)

\section{Background}

- has a doctorate, typically in education or psychology

- has some specialized self-selected optional training

- describes best preparation for ED as:

$>$ life experience

$>$ advanced education (academic/professional training)

- moved into ED after first establishing an academic career

- obtained present position through:

$>$ appointment

$>$ interests

$>$ academic qualifications

$>$ activities as an academic

\section{Professional Identity}

50\%: ED is their professional career

$50 \%$ : ED is temporary stage, or ongoing collegial role, in their academic career

\section{Responsibilities/Activities}

"any action to bring about the goal of better teaching and learning"

- advocacy

- programming

- communication

- expert consultancy

- administration

- scholarly writing and research 
institutional "pecking order" since they report directly to the chief academic officer, but are charged with bringing about change primarily through influence on those around them (as in Wright \& O'Neill, 1995). Collaborative collegial efforts with others in the university are a necessity, given these work parameters. The practitioners in this study did not suggest a different model for work conditions, but they did comment that an institutional environment that supported teaching and learning, and by extension educational development, made their work much easier.

These results suggest that there are distinct differences between those who see themselves primarily as educational development professionals, and those who see themselves as academics for whom educational development is only one component of their professional lives. Interestingly, while the study generally confirms Weimer's (1990) description of developers as an eclectic group, there are more similarities among the sub-group who see themselves as professional educational developers than among those who see it as a secondary or temporary role, suggesting that the occupation may naturally be in the process of professionalization. Still, I believe that those developers who stated that they see themselves as professional developers are really making a statement about how they see themselves (which may have some valuable, but secondary, implications for how ED work can be conceptualized). Educational development is their identity and the focus of their academic lives - i.e., saying "I am an educational developer" is comparable to saying "I am a biologist (or physician, or sociologist, or social worker)".

The differentiated profile for educational developers may be more common in Canada than in other countries. Here, both educational developers and regular faculty have always been welcome to join the country's main association for educational development concerns, the Society for Teaching and Learning in Higher Education; also, the relatively smaller population of academics, and fewer number of educational programs directly relevant to higher education, makes specialization more difficult. Should accreditation programs for educational developers, recently proposed in Britain, be encouraged in Canada? Do we wish to select (and exclude) developers with particular characteristics? The two types of practitioners noted in this study are able to offer different skills, perspectives, and knowledge background to the problem of improving teaching and learning. At the same time, the two groups are likely to have different needs in terms of their own career- and self-development. 
There is a growing interest in fostering the scholarship of teaching through educational development programs that encourage faculty to take an intellectually engaging approach (including research and writing for publication) to the improvement of teaching and learning. This study raises the question of whether educational developers' sustained involvement in ED work is essentially a scholarly activity or a different sort of professional activity. In a certain sense, professional is inseparable from scholarly in the case of educational development work in universities, since most educational developers (all in this study sample) are academics; no matter whether educational developers promote or reject a scholarly model as appropriate for educational development, they are likely to do their ED work in a scholarly fashion, given their personal identity as academics. Results from this study indicate that the typical practitioner engages in educational research and scholarship. Yet it is unclear whether they conduct research because their personal identity as academics includes a research role, or because they see educational development itself as a research inclusive activity. Those who identify themselves as educational development professionals engage in slightly more educational research than those who see themselves as academics, suggesting that these developers consider research essential to ED. However, another reason practitioners might have for adopting a scholarly model for ED is the value attached to scholarship in the university. To establish credibility for themselves and their work, it may be that educational developers must either take a scholarly approach to ED, or must establish a personal identity for themselves as scholars in another academic field.

In my experience, it is relatively uncommon for educational developers to talk publicly about their own views on teaching, apparently preferring to defer judgement to the faculty members they are trying to support. When asked in this study to describe effective teaching, their answers were remarkable in two ways. First, it appears that respondents have views that are quite similar to each other, views that can best be described as student-centered, and learner-directed. For example:

Effective teaching is giving, willingly, openly, honestly, authentically, power to learners. And truly believing in and accepting their right and responsibility to have power over their own learning. The effective educator is a catalyst, stimulant, resource, challenger, questioner. 
Effective teaching provides the most positive, open environment within which students are free to construct their own ideas and develop their own interests with full support and free from ridicule.

Good teaching helps students achieve their own goals. A good teacher is a resource, a source of experience and activities, that students can draw upon as needed.

Second, these visions of effective teaching, which correspond to theory three in Ramsden's (1992) hierarchy of three levels of understanding and performance, are not typical of most university faculty members, who generally tend to espouse a more subject-centered approach to teaching (Grabove, 1994; Wilcox, 1996) - theory one, according to Ramsden. While it is not surprising to find that educational developers would view teaching differently than other faculty, it is important to note that the differences may be quite fundamental ones.

Given that these developers espouse a student-centered and learningfocused view of undergraduate education, it is not surprising that they are dedicated to a parallel vision of educational development: they lean toward a faculty-centered, faculty-directed (and learning-focused) approach to teacher education, as has been recommended by Ramsden (1992). They believe, in other words, that faculty are responsible for their own learning and development, and that the role of the developer is to stimulate and support this process. While this is presumably a good thing, I wonder whether the faculty they work with are aware of the way these practitioners define educational development. Is it not possible that the typical faculty member conceives of educational development as programming that educational developers are responsible for? Actually, the visions of effective teaching and of effective educational development work espoused by participants in this study point to a real dilemma for educational development practitioners: how to challenge teaching conventions while supporting the faculty who are doing the teaching, and keeping these faculty directly and actively involved in development activities. These issues are educational issues, matters of concern to adult educators in a wide variety of settings. This means that there is a wider body of educational literature and practice that developers may use and contribute to (see for example, Brookfield, 1995; Cranton, 1994; Cranton, 1996).

Respondents indicated that experience was one of the best forms of preparation for ED work. They learned valuable skills, knowledge, and 
values from a wide variety of experiences, which they were then able to use in their educational development work. However, adults (and that includes educational developers) do not always learn from experiences alone. What approaches to learning educational development work are most likely to take advantage of experience as a starting and focal point for meaningful learning?

There are, at the present time, no specialized requirements for entering the field of educational development practice. A doctoral degree was the only characteristic most developers had in common, yet those who had not yet completed their doctorate did not see themselves as less skilled than their peers, nor did they view their doctoral degree as preparation for ED work. And in other Canadian universities, there are skilled and respected persons doing educational development work who do not have a doctoral degree. Apparently, anyone with interest and commitment and opportunity is able to do ED work. Yet some of the respondents demonstrated a notable concern with qualifications and with expertise - either they are overly (if understandably) mindful of status, or their experience has shown them that a particular kind of expertise IS required of educational developers. If expertise is required, what is the nature of that specialized body of knowledge, attitudes, and skills, and how is it best developed? The growing interest in professional accreditation may serve as the impetus to define the special skills and knowledge required for effective ED practice. I hope developers will be prepared for that process, with accurate and authentic descriptions of the kind of problems they address in their day-to-day work and the kind of knowledge required in practice and developed through practice.

\section{Conclusion}

This study has provided some insight into who educational developers are and how they see their work, and confirmed that many of my own ED concerns and interests are shared by other educational developers. If, as Cherryholmes proclaims, "professions are constituted by what is said and done in their names" (1988, p. 1), educational development appears to be a coherent form of professional practice for many, if not all, of those who do the work in Ontario universities. Still, my study left me wishing that there was more open and critical discussion among developers concerning the assumptions underlying our actions. What are our purposes? How can we best serve those purposes? Do we have the requisite knowledge 
and skills to facilitate the kind of educational development processes and activities that truly make a difference? If not, what can be done to ensure that those who do the work are adequately prepared for the demands of that work, and are sustained over the time it takes to do the work well? It seems to me that our commitment to improving teaching and learning allows us to accept rather too readily the current conventions of ED practice. While a commitment to doing our personal best allows us to cope admirably with the diverse demands of ED work, some further critique of the expectations we have of educational development and educational developers might well be in order.

\section{References}

Baume, D., \& Baume, C. (1994). Staff development and educational development: A discussion paper. SEDA Newsletter, 2, 6-9.

Bergquist, W.H. (1994). Unconscious values within four academic cultures. To Improve the Academy, 13, 349-372.

Brookfield, S. (1995). Becoming a critically reflective teacher. San Francisco, CA: Jossey-Bass.

Centra, J. (1976). Faculty development practices in U.S. colleges and universities (Project Report 76-30). Princeton, NJ: Educational Testing Services.

Cherryholmes, C. (1988). Power and criticism: Poststructural investigations in education. New York, NY: Teachers College Press.

Cranton, P. (1994). Self-directed and transformative instructional development. Journal of Higher Education, 65(6), 726-744.

Cranton, P. (1996). Professional development as transformative learning. San Francisco, CA: Jossey-Bass.

Donald, J.(1986). An inventory of programs, courses, and other forms of pedagogical training of higher education personnel in Canada. Report to the European Centre for Higher Education. Montreal, PQ: McGill University.

Eble, K.E., \& McKeachie, W. (1985). Improving undergraduate education through faculty development: An analysis of effective programs and practices. San Francisco, CA: Jossey-Bass.

Elrick, M. (1990). Improving instruction in universities: A case study of the Ontario Universities Program in Instructional Development. The Canadian Journal of Higher Education, 20(2), 61-79.

Erickson, G. (1986). A survey of faculty development practices. To Improve the Academy, 5, 182-196.

Gaff, J. (1975). Toward faculty renewal: Advances in faculty, instructional, and organizational development. San Francisco, CA: Jossey-Bass. 
Gosling, D. (1996). What do UK educational development units do? International Journal of Academic Development, I(1), 75-83.

Grabove, V. (1994). Instructional support for student-directed learning in an Ontario community college. Paper presented at the Annual Meeting of the Canadian Society for the Study of Higher Education, Calgary, Alberta.

Johnston, S., \& Adams, D. (1996). Trying to make a difference: Experiences of establishing a new educational development unit. International Journal of Academic Development, $1(1), 19-26$.

Lincoln, Y.S., \& Guba, E.G. (1985). Naturalistic inquiry. Beverly Hills, CA: Sage.

Lindquist, J. (Ed.). (1978). Designing teaching improvement programs. Berkeley, CA: Pacific Soundings Press.

McGrory, K. (1994). An outsider's view of POD values - and of POD's value to the academy. To Improve the Academy, 13, 373-387.

Porter, E., Lewis, K., Kristensen, E.W., Stanley, C.A., \& Weiss, C.A. (1993). Applying for a faculty development position: What can our colleagues tell us? To Improve the Academy, 12, 261-272.

Ramsden, P. (1992), Learning to teach in higher education. London: Routledge. Schein, E.H. (1972). Professional education: Some new directions. New York, NY: McGraw-Hill.

Schuster, J.H., Wheeler, D.W., \& Associates. (1990). Enhancing faculty careers: Strategies for development and renewal. San Francisco, CA: Jossey-Bass.

Sell, G.R., \& Chism, N.V. (1991). Finding the right match: Staffing faculty development centers. To Improve the Academy, 10, 19-32.

Smith, S. (1991). Report of the commission of inquiry on Canadian university education. Ottawa, ON: Association of Universities and Colleges of Canada.

Weimer, M. (1990). Improving college teaching: Strategies for developing instructional effectiveness. San Francisco, CA: Jossey-Bass.

West, P. (1989). Designing a staff development program. Journal of Further and Higher Education, 13(1), 12-18.

Wilcox, S. (1996). Fostering self-directed learning in the university setting. Studies in Higher Education, 21(2), 165-176.

Wright, W.A., \& O'Neill, M.C. (1995). Teaching improvement practices: International perspectives. In W.A.Wright \& Associates, Teaching improvement practices: Successful strategies for higher education. Bolton, MA: Anker.

Wunsch, M. (1993). From faculty developer to faculty development director: Shifting perspectives and strategies. To Improve the Academy, 12, 273-284. 


\section{Appendix A:}

\section{Summary of questions asked of Ontario Educational Developers}

1. Are you the person "in charge" (Director, for example) of instructional development activities in your university?

2. What is the title of the person you report to?

3. How many other professional/academic staff are there in your centre, besides yourself? (Include all full- and part-time appointments.)

4. Do you consider your instructional development work as

- an ongoing collegial role in addition to your primary role as an academic;

- a professional career in itself;

- a temporary stage in your academic career;

- other.

5. List primary responsibilities in instructional development.

6. Please complete a description of your background in the following areas:

a) Academic discipline.

b) Graduate degrees completed.

c) Graduate degrees in progress.

d) Any special training related to instructional development.

7. What, if any, research have you conducted on teaching and learning, or instructional development?

8. Describe how you came to be involved in ID work.

9. What in your background has best prepared you for your role as an instructional developer?

10. Describe an experience in the past six months that challenged or confirmed your ideas about ID.

11. Do you have a vision of effective teaching in higher education? Tell me what good teaching is, in your opinion.

12. Do you have a vision of effective instructional development? How would you describe an effective ID centre? 